\title{
Multimedia Based Teaching Materials for Sociolinguistics Course: A Research and Development Project (First Stage)
}

\author{
Mukhaiyar, Refnaldi, and Salam Mairi \\ Universitas Negeri Padang \\ Padang, Indonesia \\ jmukhaiyar@yahoo.com, refnaldi@yahoo.com, and salamsemangat@gmail.com
}

\begin{abstract}
It is believed that good teaching materials are the ones derived from sufficient need analysis, environment analysis, and supported by the dynamic development of knowledge and technology. This study aims to develop multimedia based teaching materials for Sociolinguistics course of the English Teaching Programs. Three research stages were conducted to complete the study; 1) definition stage, which includes need and environment analysis; 2) development stage, which includes syllabus, teaching steps, teaching materials and media, and teaching evaluation; and 3) evaluation stage, which includes expert's commentary, partial try out, and experiment. The design of this study was adjusted with each stage of the research where a survey was done in the first stage.

In the definition stage, data on need analysis and materials' relevance were collected. The need analysis shows that there is a gap between the materials being taught and the ones needed by the students. Similarly, the fitness analysis shows that the existing teaching materials are irrelevant to the students' practical learning needs. Such gap needs a bridge in a form of a corresponding new teaching and learning model to help students in learning Sociolinguistics.

Due to some practical requirements and limitations related to the conference event, this paper only presents the first stage of the study. The later stages are to be discussed in different articles and to be presented in other conferences.
\end{abstract} syllabus

Keywords-Sociolinguistics; multimedia; learning strategies;

\section{INTRODUCTION}

Technology in education is a systematic approach in defining education goals and analysis related to teaching and learning process. It is a 'problem solving' approach toward education. Universitas Negeri Padang as a higher education provider has been vastly influenced by technology development in education, especially in the use of multimedia. It can be seen from its use in several classes such as Reading, Structure, Listening, Speaking, Writing, and Computer Assisted Language Learning (CALL) offered by the English Teaching Program. Other courses except the above-mentioned are currently undergoing the adaptation process of utilizing multimedia in teaching and learning.

Sociolinguistics is one of the compulsory courses which have not utilized multimedia and technology in delivering its materials. The course is deemed essential as it helps students to understand and implement the principles of language use within the real contexts. To be able to make the most of their language learning achievements, students are required to analyze and comprehend language use phenomenon within the community. Such contexts-based understanding is necessary for them to perfectly know and decide the best practice of English use in any setting it is required.

\section{REVIEW OF RELATED THEORIES}

A. Teaching and Learning Model Development

It is a fundamental process where series of activities are done to plan, develop, and evaluate the existing model to meet the needs and expectations of all parties involved. The output of the development is a better teaching and learning system supplemented by empirically and consistently improved materials and strategies to achieve the goals [1]. Reference [2] proposes clear objectives, goals-curriculum relevance, objectives coverage, strategies, interaction, motivation, contexts, materials and scaffolding, goalsmaterials relevance, materials quality, ease, systematic structure, simulation, evaluation, and feedback as vital aspects of teaching and learning model. Thus, it is comprehended that a teaching and learning model includes materials and techniques which are improved empirically and consistently to achieve the goals and objectives. Further, it becomes the solution to the existing problems and issues in teaching and learning. The models and aspects of teaching and learning discussed above are parts of the conceptual frame to be used for development. The key point is for the teachers to organize and develop such components in good planning by considering actual conditions of supporting items including time allocation, facilities, and funding.

B. Need Analysis

The design of a teaching and learning model is started from questioning students' motivation in learning sociolinguistics. Reference [3] explains that the term 'need analysis' refers to a technique of data collection and data analysis related to students' needs in learning. It is a continuous process involving modifications of teaching and learning process in order to accommodate students' needs. Similarly, [4] argues that 'need analysis' is a systematic process to identify learners' needs and tendencies to be interpreted. The interpretation of the need will then be the guidance in composing the lessons to achieve the needs or goals of teaching and learning. 
In fact, need analysis is only one out of various activities conducted in creating a well-established curriculum of language learning. Reference [5] proposes that a model contains three external circles (principles, environments, needs) which are strongly related to one internal circle (objectives) and supported by three components (structure, format and presentation, monitoring and assessment). In addition, there are several goals of doing need analysis in language learning as proposed by [6] such as identifying learners' expected role in using a language, selecting appropriate teaching and learning materials, grouping learners' levels of proficiency and needs, recognizing individual potentials in the group, detecting learners' feasible reach and outreach in learning, and collecting learners' experience in dealing with issues in language learning.

In terms of need analysis, it can be concluded that it is a process of collecting and analyzing information related to what students should learn, what they do not understand, and what they want to achieve from their learning experiences.

\section{Learning Sociolinguistics}

Language in its relation to culture and use in community should be viewed from two perspective, form and function. Language in its use does not only represent symbols containing meanings but also signs of contexts which are full of interpretations and values. All utterances are delivered in contexts and are inseparable from them. This phenomenon carries special characteristics to the messages being delivered. It could be described in the fact that members of communities are differed in age, sex, education, job, and social status which use different characters of language in communication.

In linguistics study, sociolinguistics is known for its focus on the relations between language and its users or the community. It discusses the situations and conditions of the language users (community) which later influence the language either in forms or functions. These elements interact with each other without isolation [7]. In addition, [8] argues that social identity plays a crucial role in manipulating language use in multilingual community. The social identity is reflected in aspects such as age, sex, education, job, and social status presented within their communication among community members. According to [9], there are seven areas of research within the study of sociolinguistics such as social identity of the user, social identity of the interlocutor, the social environment of the occurrences, synchronic and diachronic analysis of the local dialects, users' interpretation of the utterances, linguistics variations, and practical implementation of sociolinguistics studies.

In accordance to the above elaboration on sociolinguistics, it is necessary for the learners to acquire sufficient understanding on socio-cultural aspects of a language (English) in order to make the most of their learning experience in its real-contexts use.

\section{Multimedia}

Multimedia has been equipped in learning process because it helps learners and teachers interaction. Besides, it also helps stimulating learners' participation in the learning process [10]. It is the combination of audio, image, graphic, video, text, and animation in a dynamic and interactive manner [11]. It has been proven empirically that the use of multimedia in teaching and learning process contributes to the improvement of learners' interest and participation. Such interest and participation can be interpreted as positive interaction in classroom setting.

\section{METHOD}

This is a Research and Development study where the objective is to develop an effective model of teaching and learning for Sociolinguistics course at the English Department of Universitas Negeri Padang. Research and Development is favorable in the area of educational research because of its relation to program evaluation and development [12]. In terms of method, the study employs mixed-method techniques where both qualitative and quantitative methods are used.

A. The instrumentations of the study are as the following:

- Survey: It is used to identify the needs of both lecturers and students of Sociolinguistics course of the English Teaching Program at Universitas Negeri Padang.

- Content Analysis: This method is used to pinpoint the relevance of the teaching and learning materials provided by the lecturers of Sociolinguistics course of the English Teaching Program at Universitas Negeri Padang.

\section{B. Data Collection}

The population of this study was 155 students of the English Teaching Program at Universitas Negeri Padang. Two sets of questionnaires are distributed to the participants. The first set of questionnaires asks about problems faced by the students in learning Sociolinguistics during their class. The second set of questionnaires asks about their needs and expectations of what to achieve from the Sociolinguistics class. The table 1 describes the details of data collection phase:

Table 1. Data, Source, Collection Technique, and Instrument

\begin{tabular}{|c|l|c|l|c|c|}
\hline No & \multicolumn{1}{|c|}{ Item } & Method & Source & Technique & Instrument \\
\hline 1 & $\begin{array}{l}\text { Students' } \\
\text { needs and } \\
\text { expectatio } \\
\text { ns of what } \\
\text { to achieve } \\
\text { from the } \\
\text { Socioling } \\
\text { uistics } \\
\text { class }\end{array}$ & & $\begin{array}{l}\text { Quantitative } \\
\text { Sho just } \\
\text { completed } \\
\text { Socioling } \\
\text { uistics } \\
\text { course }\end{array}$ & Survey & Questionnaire \\
\hline 2 & $\begin{array}{l}\text { The } \\
\text { perception } \\
\text { s on } \\
\text { existing } \\
\text { materials } \\
\text { appropriat } \\
\text { eness }\end{array}$ & Qualitative & $\begin{array}{l}\text { Three } \\
\text { Socioling } \\
\text { uistics }\end{array}$ & Evaluation & \\
course & & \\
lecturers & & \\
Form & \\
& & & & \\
\end{tabular}

\section{Data Analysis}

The technique used for data analysis varies between methods, according to its research purpose. To analyze the quantitative data generated from the survey, all answers were converted into scores. The option 'never' is valued one, 
'sometime' is valued two, 'often' is valued three, and 'very often' is valued four. Then, the average score for each option is classified into predetermined categories for grouping purpose where on 'problems face by students in learning Sociolinguistics': $1.00-1.75$ means low/no problematic, 1.76 - 2.50 means medium/ no problematic, 2.51 - 3.25 means high/problematic, and $3.26-4.00$ means very high/problematic. Differently, on 'students' expectation on a learning model' $1.00-1.75$ means not important/not prioritized, $1.76-2.50$ means less important/not prioritized, $2.51-3.25$ means important/ prioritized, and $3.26-4.00$ means very important/ prioritized.

\section{A. Students' Need Analysis}

\section{FINDING AND DISCUSSION}

It is fundamental to assess students' needs by conducting need analysis. It helps the developer or whoever in charge as stakeholders in curriculum or teaching and learning development to plan and organize the best output possible. The following section discusses the findings on students' need analysis related to multimedia based teaching and learning model for Sociolinguistics course.

- Topic/Sub-topic in Sociolinguistics

In order to gather detailed information related to topics/subtopics taught in Sociolinguistics class, 27 questions were formulated and distributed to the respondents of the study. The results present the level of importance of each topic/subtopic as described in the table 2 .

Table 2. Answers on the importance of topics/subtopics

\begin{tabular}{|c|l|c|c|c|c|c|c|c|}
\hline No & \multicolumn{1}{|c|}{ Item } & NI & LI & I & VI & Total & Average Category \\
\hline 1 & $\begin{array}{l}\text { Language } \\
\text { planning and } \\
\text { policy }\end{array}$ & 6 & 52 & 201 & 224 & 483 & 3.12 & $\mathrm{H}$ \\
\hline 2 & $\begin{array}{l}\text { Code switching } \\
\text { and code mixing }\end{array}$ & 9 & 42 & 237 & 184 & 472 & 3.05 & $\mathrm{H}$ \\
\hline 3 & $\begin{array}{l}\text { Ethnography } \\
\text { and ethno } \\
\text { methodology }\end{array}$ & 10 & 34 & 267 & 156 & 467 & 3.01 & $\mathrm{H}$ \\
\hline 4 & $\begin{array}{l}\text { Sociolinguistics } \\
\text { and education }\end{array}$ & 22 & 48 & 120 & 276 & 466 & 3.01 & $\mathrm{H}$ \\
\hline 5 & $\begin{array}{l}\text { Language death } \\
\text { and language } \\
\text { loss }\end{array}$ & 17 & 60 & 150 & 232 & 459 & 2.96 & $\mathrm{H}$ \\
\hline 6 & $\begin{array}{l}\text { Pidgins and } \\
\text { creoles }\end{array}$ & 15 & 48 & 210 & 184 & 457 & 2.95 & $\mathrm{H}$ \\
\hline 7 & $\begin{array}{l}\text { What do } \\
\text { sociolinguistics } \\
\text { study }\end{array}$ & 15 & 50 & 210 & 180 & 455 & 2.94 & $\mathrm{H}$ \\
\hline 8 & $\begin{array}{l}\text { Language } \\
\text { maintenance } \\
\text { and shift }\end{array}$ & 18 & 48 & 189 & 200 & 455 & 2.94 & $\mathrm{H}$ \\
\hline 9 & Social dialects & 13 & 64 & 210 & 160 & 447 & 2.88 & $\mathrm{H}$ \\
\hline 10 & $\begin{array}{l}\text { Ethnicity and } \\
\text { social networks }\end{array}$ & 15 & 54 & 225 & 152 & 446 & 2.88 & $\mathrm{H}$ \\
\hline 11 & $\begin{array}{l}\text { Sociolinguistics } \\
\text { and Sociology } \\
\text { of Language }\end{array}$ & 21 & 50 & 192 & 180 & 443 & 2.86 & $\mathrm{H}$ \\
\hline 12 & $\begin{array}{l}\text { Language } \\
\text { change }\end{array}$ & 18 & 180 & 180 & 442 & 2.85 & $\mathrm{H}$ \\
\hline
\end{tabular}

Table 2. Cont

\begin{tabular}{|l|l|c|c|c|c|c|c|c|}
\hline 13 & $\begin{array}{l}\text { Speech } \\
\text { functions }\end{array}$ & 20 & 50 & 210 & 160 & 440 & 2.84 & $\mathrm{H}$ \\
\hline 14 & $\begin{array}{l}\text { Language and } \\
\text { culture }\end{array}$ & 25 & 42 & 195 & 176 & 438 & 2.83 & $\mathrm{H}$ \\
\hline 15 & $\begin{array}{l}\text { Cross cultural } \\
\text { communication }\end{array}$ & 21 & 76 & 150 & 184 & 431 & 2.78 & $\mathrm{M}$ \\
\hline 16 & $\begin{array}{l}\text { Language } \\
\text { attitudes }\end{array}$ & 27 & 50 & 177 & 176 & 430 & 2.77 & $\mathrm{M}$ \\
\hline 17 & $\begin{array}{l}\text { Style, context } \\
\text { and register }\end{array}$ & 25 & 50 & 207 & 144 & 426 & 2.75 & $\mathrm{M}$ \\
\hline 18 & $\begin{array}{l}\text { Language } \\
\text { attrition }\end{array}$ & 21 & 66 & 195 & 144 & 426 & 2.75 & $\mathrm{M}$ \\
\hline 19 & Diglossia & 16 & 100 & 177 & 120 & 413 & 2.66 & $\mathrm{M}$ \\
\hline 20 & $\begin{array}{l}\text { Language and } \\
\text { gender }\end{array}$ & 27 & 70 & 177 & 136 & 410 & 2.65 & $\mathrm{M}$ \\
\hline 21 & Lingua franca & 19 & 86 & 204 & 100 & 409 & 2.64 & $\mathrm{M}$ \\
\hline 22 & $\begin{array}{l}\text { Language } \\
\text { transfers }\end{array}$ & 32 & 76 & 135 & 160 & 403 & 2.6 & $\mathrm{M}$ \\
\hline 23 & $\begin{array}{l}\text { Acting and } \\
\text { conversing }\end{array}$ & 28 & 78 & 180 & 112 & 398 & 2.57 & $\mathrm{M}$ \\
\hline 24 & Politeness & 30 & 70 & 198 & 96 & 394 & 2.54 & $\mathrm{M}$ \\
\hline 25 & $\begin{array}{l}\text { Regional } \\
\text { dialects }\end{array}$ & 24 & 96 & 195 & 72 & 387 & 2.5 & $\mathrm{M}$ \\
\hline 26 & $\begin{array}{l}\text { Vernacular and } \\
\text { standard } \\
\text { languages }\end{array}$ & 30 & 74 & 219 & 60 & 383 & 2.47 & $\mathrm{M}$ \\
\hline 27 & $\begin{array}{l}\text { Bilingualism } \\
\text { and } \\
\text { multilingualism }\end{array}$ & 53 & 90 & 84 & 116 & 343 & 2.21 & $\mathrm{M}$ \\
\hline
\end{tabular}

$\mathrm{NI}=$ Not Important, LI= Less Important, I= Important, $\mathrm{VI}=$ Very Important

In general, the table shows that none of the topics/subtopics categorized as Very High (VH), Low (L), or Very Low (VL). In fact they are either High $(\mathrm{H})$ or Medium (M). 14 of the topics/subtopics are categorized as High $(\mathrm{H})$ and 13 topics are categorized as Medium (M). Therefore, it can be inferred that more than $50 \%$ of the topics/subtopics offered in Sociolinguistics class are considered important by the students. In addition, the above table specifically tells that Language Planning and Policy (483) followed by Code switching and code mixing (472), Ethnography and Ethnomethodology (467), Sociolinguistics and Education (466), Language Death and Language Loss (459), Pidgins and Creoles (457), and Language Maintenance and Shift and What Do Sociolinguistics Study (both 455) are considered the most important topics/subtopics in the Sociolinguistics class.

The Language Planning and Policy gets the highest score because of its relation to the very principle of sociolinguistics course. Sociolinguistics is the study of how a language is used contextually in the community. Thus, the students need to be introduced to the real use of language and the role played by the government as the policy-maker in planning and developing the language related to how it may contribute to the country development. For instance, the politics of national language, regional language, and foreign language of a country are deemed crucial for the students to comprehend through the study of sociolinguistics. Later, they will be able to make use of such knowledge as initial insights to their teaching practice. 
The second most important of all topics/subtopics is Code Switching and Code Mixing. This particular field helps them understand the reasons of selecting codes, types of codes switching, differences between code switching and code mixing, and community's perception on individuals who frequently do code mixing. These add up to their previously acquired knowledge related to sociolinguistics.

The next topic/subtopic considered important is Ethnography and Ethnomethodology. It is necessary for the students to learn how language is used communicatively through the eye of ethnography. The aspects of setting, participant, end, acts, and keys influence the way people use a language, which are significant in the study of sociolinguistics. Besides, the knowledge of strategies people use in a conversation is also essential in the scope of ethnomethodology. The strategies include turn-taking, turngetting, overlapping, interrupting, repair, adjacency pairs, and insertion sequence. These all play significant role on how people use a language (English) to produce well-established conversation.

Following Ethnography and Ethnomethodology, Sociolinguistics and Language Education scored considerably high as it is a part of Applied Sociolinguistics. Being English teachers requires them to understand the relation between the study of Sociolinguistics and the study of language teaching or language education. Especially in English, there are varieties of English used by people to communicate worldwide, where English has become the lingua franca. After all, the importance of these topics/subtopics are relevant to reasonable argumentation on why they are offered in the very first place, and the students responded by their original perception based on learning practices and experiences related to the course of Sociolinguistics.

- Tasks/Exercises in Sociolinguistics

The study analyzes types of tasks in Sociolinguistics class which are considered significant by the students. Therefore, 27 questions related to the given tasks/exercises were distributed to the 155 students. The results of the questionnaire are described in the table 3:

Table 3. Answers on the importance of tasks/exercises

\begin{tabular}{|c|l|c|c|c|c|c|c|c|}
\hline No & Item & NI & LI & I & VI & Tota & Average & $\begin{array}{c}\text { Categor } \\
\mathbf{y}\end{array}$ \\
\hline 1 & $\begin{array}{l}\text { Code switching } \\
\text { and code mixing }\end{array}$ & 21 & 18 & 237 & 184 & 460 & 2.97 & $\mathrm{H}$ \\
\hline 2 & $\begin{array}{l}\text { Ethnography and } \\
\text { ethnomethodology }\end{array}$ & 13 & 38 & 249 & 160 & 460 & 2.97 & $\mathrm{H}$ \\
\hline 3 & Politeness & 20 & 48 & 195 & 184 & 447 & 2.88 & $\mathrm{H}$ \\
\hline 4 & $\begin{array}{l}\text { Language } \\
\text { maintenance and } \\
\text { shift }\end{array}$ & 24 & 42 & 186 & 192 & 444 & 2.86 & $\mathrm{H}$ \\
\hline 5 & Language attrition & 17 & 66 & 180 & 180 & 443 & 2.86 & $\mathrm{H}$ \\
\hline 6 & Language change & 18 & 64 & 180 & 180 & 442 & 2.85 & $\mathrm{H}$ \\
\hline 7 & Language attitudes & 27 & 46 & 183 & 176 & 432 & 2.79 & $\mathrm{M}$ \\
\hline 8 & Speech functions & 25 & 60 & 180 & 160 & 425 & 2.74 & $\mathrm{M}$ \\
\hline 9 & $\begin{array}{l}\text { Language and } \\
\text { gender }\end{array}$ & 27 & 50 & 207 & 136 & 420 & 2.71 & $\mathrm{M}$ \\
\hline 10 & $\begin{array}{l}\text { Acting and } \\
\text { conversing }\end{array}$ & 27 & 56 & 195 & 140 & 418 & 2.7 & $\mathrm{M}$ \\
\hline
\end{tabular}

Table 3. Cont

\begin{tabular}{|c|c|c|c|c|c|c|c|c|}
\hline 11 & $\begin{array}{l}\text { Cross cultural } \\
\text { communication }\end{array}$ & 38 & 42 & 156 & 176 & 412 & 2.66 & M \\
\hline 12 & $\begin{array}{l}\text { Language death } \\
\text { and language loss }\end{array}$ & 16 & 100 & 186 & 108 & 410 & 2.65 & M \\
\hline 13 & Language transfers & 32 & 56 & 174 & 148 & 410 & 2.65 & $\mathrm{M}$ \\
\hline 14 & $\begin{array}{l}\text { What do } \\
\text { sociolinguistics } \\
\text { study }\end{array}$ & 25 & 100 & 135 & 140 & 400 & 2.58 & M \\
\hline $\begin{array}{l}1 \\
5\end{array}$ & $\begin{array}{l}\text { Style, context and } \\
\text { register }\end{array}$ & 38 & 50 & 201 & 100 & 389 & 2.51 & M \\
\hline $\begin{array}{l}1 \\
6\end{array}$ & Pidgins and creoles & 24 & 92 & 210 & 60 & 386 & 2.49 & M \\
\hline $\begin{array}{l}1 \\
7\end{array}$ & Regional dialects & 25 & 96 & 195 & 68 & 384 & 2.48 & M \\
\hline $\begin{array}{l}1 \\
8\end{array}$ & $\begin{array}{l}\text { Language and } \\
\text { culture }\end{array}$ & 21 & 108 & 195 & 60 & 384 & 2.48 & M \\
\hline $\begin{array}{l}1 \\
9\end{array}$ & Social dialects & 33 & 84 & 180 & 80 & 377 & 2.43 & M \\
\hline $\begin{array}{l}2 \\
0 \\
\end{array}$ & \begin{tabular}{|l|}
$\begin{array}{l}\text { Ethnicity and } \\
\text { social networks }\end{array}$ \\
\end{tabular} & 25 & 146 & 87 & 112 & 370 & 2.39 & M \\
\hline $\begin{array}{l}2 \\
1\end{array}$ & $\begin{array}{l}\text { Language planning } \\
\text { and policy }\end{array}$ & 45 & 68 & 150 & 104 & 367 & 2.37 & M \\
\hline $\begin{array}{l}2 \\
2 \\
\end{array}$ & \begin{tabular}{|l|}
$\begin{array}{l}\text { Vernacular and } \\
\text { standard languages }\end{array}$ \\
\end{tabular} & 39 & 74 & 189 & 64 & 366 & 2.36 & M \\
\hline $\begin{array}{l}2 \\
3\end{array}$ & $\begin{array}{l}\text { Sociolinguistics } \\
\text { and education }\end{array}$ & 33 & 116 & 120 & 96 & 365 & 2.35 & M \\
\hline $\begin{array}{l}2 \\
4\end{array}$ & Diglossia & 33 & 100 & 177 & 52 & 362 & 2.34 & M \\
\hline $\begin{array}{l}2 \\
5\end{array}$ & Lingua franca & 35 & $\mid 136$ & 81 & 100 & 352 & 2.27 & M \\
\hline $\begin{array}{l}2 \\
6\end{array}$ & \begin{tabular}{|l}
$\begin{array}{l}\text { Bilingualism and } \\
\text { multilingualism }\end{array}$ \\
\end{tabular} & 53 & 90 & 84 & 116 & 343 & 2.21 & M \\
\hline $\begin{array}{l}2 \\
7\end{array}$ & $\begin{array}{l}\text { Sociolinguistics } \\
\text { and Sociology of } \\
\text { Language }\end{array}$ & 71 & 102 & 60 & 52 & 285 & 1.84 & $\mathrm{~L}$ \\
\hline
\end{tabular}

$\mathrm{NI}=$ Not Important, LI= Less Important, I= Important, VI= Very Important

It can be seen from the table above that tasks/exercises related to Code Switching and Code Mixing (460) and those related to Ethnography and Ethnomethodology (460) are the most important ones. It is believed to be the results of students' understanding and comprehension on how Sociolinguistics is strongly related to the practical use of language (English) in the contexts among community members in the society. Therefore, they are aware of the need to for such tasks/practices. In addition, in terms of Ethnography and Ethnomethodology topic, students need to practice the decision-making by taking setting, participants, ends, key, instrument, genre, turn-taking, turn getting, repair, overlapping, back-channels, and other aspects into account. After all, these components of knowledge are crucial for them as many of them aspire to be English teachers. They need to understand how a language is used, how it is maintained and how it is modified or degraded in the real-setting use in the community.

\section{- Media in Sociolinguistics}

In order to identify the types of media preferred or considered important by the students, 10 questions were 
distributed through the questionnaire. The responses to the 10 items are ranked in the table 4 :

Table 4. Types of media based on the level of importance

\begin{tabular}{|c|l|c|c|c|c|c|}
\hline No & \multicolumn{1}{|c|}{ Item } & NI & LI & I & VI & Total \\
\hline 1 & $\begin{array}{l}\text { Digital presentation } \\
\text { through Power Point }\end{array}$ & 0 & 6 & 156 & 128 & 290 \\
\hline 2 & $\begin{array}{l}\text { Digital presentation } \\
\text { through interactive } \\
\text { multimedia platform }\end{array}$ & 0 & 18 & 123 & 148 & 289 \\
\hline 3 & $\begin{array}{l}\text { Written materials in } \\
\text { modules }\end{array}$ & 0 & 40 & 153 & 92 & 285 \\
\hline 4 & $\begin{array}{l}\text { Tasks/exercises through } \\
\text { interactive multimedia } \\
\text { digital platform }\end{array}$ & 4 & 72 & 90 & 104 & 270 \\
\hline 5 & $\begin{array}{l}\text { Tasks/exercises through } \\
\text { Power Point presentation }\end{array}$ & 1 & 28 & 150 & 84 & 263 \\
\hline 6 & Written tasks/exercises & 2 & 26 & 162 & 72 & 262 \\
\hline 7 & $\begin{array}{l}\text { Verbal delivery of the } \\
\text { materials through audio- } \\
\text { visual recording }\end{array}$ & 2 & 50 & 114 & 88 & 254 \\
\hline 8 & $\begin{array}{l}\text { Verbal delivery of the } \\
\text { materials through audio } \\
\text { recording }\end{array}$ & 7 & 106 & 60 & 48 & 221 \\
\hline 9 & $\begin{array}{l}\text { Verbal delivery of the } \\
\text { tasks/exercises through } \\
\text { audio-visual recording }\end{array}$ & 10 & 74 & 90 & 40 & 214 \\
\hline 10 & $\begin{array}{l}\text { Verbal delivery of the } \\
\text { tasks/exercises through } \\
\text { audio recording }\end{array}$ & 12 & 82 & 81 & 28 & 203 \\
\hline
\end{tabular}

The table above shows that the students believe it is important for them to learn their lessons through materials being delivered on the basis of current technology. It could be delivered simply by the use of Power Point presentation or more advance media by using the latest computer softwares available in the market. The technology will allow them to do independent practices to further understand the concepts, access extended examples and exercises, or learn individually.

Based on the findings, it can be concluded that the Sociolinguistics learning materials are reasonably developed and used. Although, there are opportunities for improvement in many aspects. One of those are design and structure of the learning materials as well as those related to tasks/exercises parts. In addition, the use of technology for the development of learning materials is also considered urgent. It is believed that the use of such media in Sociolinguistics course will increase students' interest and motivation in studying the course.

\section{CONCLUSION}

Based on research development from stage to stage, specifically on stage one, it can be concluded that the most suitable model of teaching and learning Sociolinguistics in the English Teaching Program at Universitas Negeri Padang is the one with attractive design, accommodates both lecturers' and students' needs and expectations, and supported by technology development. Course's contribution to both lecturers' and students' expected experience in Sociolinguistics class is fundamental to meet the preset goals of teaching and learning. In addition, it is very important to assure its attractiveness via multimedia combined with technology development because it helps increase students' interest and participation in the teaching and learning process. Moreover, in its development, technology integration into the classroom is inevitable to support even better learning environment. With these points being kept in mind, the development process shall progress. Later, the proposed model which will be presented separately should consist at least three components such as syllabus, teaching and learning strategies prototype, and three-versions learning materials. The three versions are in forms of print out (conventional), audio/video, and digital through software for independent learning.

\section{References}

[1] Harjanto. "Perencanaan pengajaran". Rineka Cipta, 2011

[2] Pribadi, Benny A. "Model desain system pembelajaran". Dian Rakyat, 2009.

[3] Hyland, Ken. "Second language writing". Cambridge University Press. 2003.

[4] Morrison, R. Gary, Steven M. Ross and Jerrold E. Kemp. "Designing effective instruction (5th Edition)". Jhon Wiley \& Sons, Inc, 2007.

[5] Tomlinson, Brian. "Materials development in language teaching". Cambridge University Press, 2011.

[6] Richards, Jack C. "Curriculum development in language teaching". Cambridge University Press, 2001.

[7] Wardaugh, Ronald. "An introduction to sociolinguistics ( $6^{\text {th }}$ Edition)" Blackwell Publishing, 2010.

[8] Holmes, Janet. "An introduction to sociolinguistics ( $3^{\text {rd }}$ Edition)". Longman, 2010.

[9] Chaer, Abdul, and Leonie Agustina. "Sosiolinguistik: Perkenalan awal". Rineka Cipta, 2004.

[10] Winataputra, Udin S. "Model-model pembelajaran inovatif". Pusat Antar Universitas, 2001.

[11] Miarso, Yusufhadi. "Definisi teknologi pendidikan". Rajawali, 1986.

[12] Gall, Meredith Damien, Walter R. Borg, and Joyce P. Gall. "Educational research: An introduction ( $7^{\text {th }}$ Edition)". Pearson Education, 2003. 